\title{
Mathematical Modeling for Isotherms of Mango Pulp Powder, Obtained by Atomization
}

\author{
Érica Milô de Freitas Felipe Rocha ${ }^{1 *}$, Sueli Rodrigues², \\ Marcos Rodrigues Amorim Afonso ${ }^{2}$, José Maria Correia da Costa ${ }^{2}$ \\ ${ }^{1}$ Federal Institute of Education, Science and Technology of Rio Grande do Norte, Fortaleza, Brazil \\ ${ }^{2}$ Federal University of Ceará, Fortaleza, Brazil \\ Email: emffrocha@yahoo.com.br, sueli@ufc.br, m.r.a.afonso@gmail.com, correiacostaufc@gmail.com
}

Received 12 January 2014; revised 12 February 2014; accepted 19 February 2014

Copyright (C) 2014 by authors and Scientific Research Publishing Inc.

This work is licensed under the Creative Commons Attribution International License (CC BY). http://creativecommons.org/licenses/by/4.0/

CC) (i) Open Access

\begin{abstract}
Mango, as the other fruits, is a perishable food that can be easily deteriorated and presents high levels of post-harvest loss. Therefore, dehydration is an important alternative to use the production excess. In this context, this work aimed at evaluating the hygroscopic behavior of the integral mango pulp powder, obtained by atomization, by means of adsorption isotherm. After applying BET's, GAB's, Henderson's and Oswin's mathematical models, it was possible to identify that the equations for two models were perfectly adjusted to the experimental results of mango pulp powder. Henderson's model was the best adjusted experimental curve and showed the lowest average error $(E)$ and the highest determination coefficient $\left(R^{2}\right)$ at all temperatures studied.
\end{abstract}

\section{Keywords}

Spray-Dryer; Water Activity; Hygroscopicity; Mathematical Models

\section{Introduction}

Mango is considered one of the most important tropical fruits in the world. In America, Brazil was the first country to cultivate it, mainly in Rio de Janeiro, and from this state, the first plants spread to other areas of the country. Besides its fresh consumption, Mango can be used for the making of several industrialized products, since it is a source of vitamins A and C [1]. According to some data from IBGE [2], in 2011, Brazil produced

${ }^{*}$ Corresponding author.

How to cite this paper: de Freitas Felipe Rocha, É.M., et al. (2014) Mathematical Modeling for Isotherms of Mango Pulp Powder, Obtained by Atomization. Journal of Encapsulation and Adsorption Sciences, 4, 8-14. 
1,249,521 tons of mangos, and the Northeastern Region was responsible for $70.24 \%$ of this production.

It is important to highlight that the quality and useful life of powder products, such as mango pulp powder obtained in this research, are strongly connected to the concentration and mobility of water in their structure, because water exercises greatly influence both the microbial growth and palatability, digestibility, physical structure and handling.

The study of water activity can be carried out by evaluating isotherms, which are curves that describe the relation between moisture content in food and water activity $\left(a_{w}\right)$ for constant temperature and pressure. Moisture sorption isotherms (adsorption and desorption) are applied to predict drying time and shelf life, to determine the kind of packaging and to characterize the product, especially when it consists of different water activity components [3].

Anselmo et al. [4] highlight that, in the production of pulverized fruits, the isotherms of hygroscopic balance of a product aim at establishing whether the product, under specific conditions of temperature, and relative humidity tends to sorb or desorb water. In this sense, powder pulps keep a strong relation between quality and useful life and water content, since it influences palatability, digestibility, physical structure and handling [5].

Moreover, it is important to highlight that mathematical models have been proposed, in order to obtain adsorption isotherms for food. However, most models-empiric, semi-empiric and theoretical—are only precise upon a limited range of water activity and some types of food. It is also important to emphasize that there is no general equation for food isotherms, since water activity depends a lot on its composition and on the interaction between different constituents and water under conditions of thermodynamic balance [6].

Given the above, this work aimed at evaluating hygroscopic behavior by means of mathematical models applied to the adsorption isotherms of integral mango pulp powder.

\section{Material and Methods}

Mango pulp powder was used as raw material. It was obtained by spray-dryer (model LM MSD 1.0-Labmaq) with an asperser beak of $1.2 \mathrm{~mm}$ in diameter and under the following variables: hot air output $\left(3.75 \mathrm{~m}^{3} / \mathrm{min}\right)$, feeding speed $(0.55 \mathrm{~L} / \mathrm{h})$, input air temperature $\left(178^{\circ} \mathrm{C}\right)$, maltodextrin $20 \mathrm{DE}$ concentration $(30 \%)$, air speed $(3.0$ $\mathrm{L} / \mathrm{min}$ ) and atomization pressure (100 psi).

All analytical determinations were carried out in triplicates, and they were: water activity in the powder, using a water activity measurer (model AQUALab $4 \mathrm{TEV}$ ), at $25^{\circ} \mathrm{C}, 30^{\circ} \mathrm{C}, 35^{\circ} \mathrm{C}$ and $40^{\circ} \mathrm{C}$, according to the manufacturer's indications [7], and the determination of adsorption isotherms, where the static gravimetric method was applied, as described by Spiess and Wolf [8], using saturated salt solutions, such as $\mathrm{CH}_{3} \mathrm{COOK}(21 \%), \mathrm{K}_{2} \mathrm{CO}_{3}$ (44\%), $\mathrm{NaBr}$ (58\%), $\mathrm{SnCl}_{2}$ (76\%), $\mathrm{KCl}$ (84\%) and $\mathrm{BaCl}_{2}$ (90\%), prepared in accordance with Greenspan [9].

For the mathematical adjustment of the experimental data, we used BET's, GAB's, Henderson's and Oswin's mathematical models, which are represented, respectively, by the following equations:

$$
\begin{gathered}
\text { BET: } X_{e q}=\frac{X_{m} \cdot C \cdot a_{w}}{\left(1-a_{w}\right)} \cdot\left[\frac{1-(n+1) \cdot\left(a_{w}\right)^{n}+n \cdot\left(a_{w}\right)^{n+1}}{1-(1-C) \cdot a_{w}-C \cdot\left(a_{w}\right)^{n+1}}\right] \\
\text { GAB: } X_{e q}=\frac{X_{m} \cdot C \cdot K \cdot a_{w}}{\left(1-K \cdot a_{w}\right) \cdot\left(1-K \cdot a_{w}+C \cdot K \cdot a_{w}\right)} \\
\text { Henderson: } X_{e q}=\left[\frac{-\ln \left(1-a_{w}\right)}{b}\right]^{\frac{1}{a}} \\
\text { Oswin: } X_{e q}=a \cdot\left[\frac{a_{w}}{1-a_{w}}\right]^{b}
\end{gathered}
$$

where: $a_{w}=$ water activity; $X_{m}=$ moisture content in the molecular monolayer $\left(\mathrm{g} \cdot \mathrm{g}^{-1} \mathrm{in}\right.$ a dry basis); $X_{e q}=$ balance moisture content ( $\mathrm{g} \cdot \mathrm{g}^{-1}$ in a dry basis); $C=$ BET's constant related to the sorption heat of the molecular layer; $n=$ number of molecular layers; $K=$ sorption constant of the model; $a$ and $b=$ adjustment parameters.

The values for error $(E)$ were calculated in accordance with Equation (5), as described by Toloba et al. [10]: 


$$
E=\frac{100}{n} \sum_{i=1}^{n} \frac{\left|\left(M_{i}-M p_{i}\right)\right|}{M_{i}}
$$

where: $E$ = average relative error; $M_{i}=$ values obtained experimentally; $M_{p i}=$ values predicted by the model; $n=$ number of experimental data.

\section{Results and Discussion}

In Table 1, the values obtained for water activity $\left(a_{w}\right)$ and unit of balance $\left(X_{e q}\right)$ for mango pulp powder at each tested temperature are displayed. It is possible to observe that water activity tends to decrease as temperature increases, indicating that mango pulp powder becomes less hygroscopic.

From the values for $a_{w}$ and $X_{e q}$ displayed on Table 1, the adjustments for GAB's, BET's, Herderson's and Oswin's models were made. The results for the parameters of these models, as adjusted to the experimental data for the construction of adsorption isotherms for mango pulp powder, in addition to the determination coefficient $\left(R^{2}\right)$ and the average relative error $(E \%)$ are displayed on Table 2. In this table, it is possible to observe that, for mango pulp powder, Henderson's models was the one that adjusted the best to the experimental curve, showing the lowest average relative error $(E \%)$ and the highest determination coefficient $\left(R^{2}\right)$, at all temperatures.

According to the criteria established by Park, Bin and Brod [11], values of $E$ (\%) lower than $10 \%$ indicate a reasonable adjustment for the practices and Labuza, Kaanane and Chen [12] say that the representation of isotherms is considered as extremely good for values of $E(\%)$ lower than $5 \%$.

The second model that best represented these experimental data was GAB's. BET's model was the one that worst represented the data in question. The values for determination coefficients $\left(R^{2}\right)$ were higher than 0.99 in all models; therefore, it is possible to affirm that the equations were properly adjusted to the experimental results for mango pulp powder. Given this, the main results were discussed and the sorption isotherms for the best models (Henderson's and GAB's) were elaborated.

For mango pulp powder, at $25^{\circ} \mathrm{C}, 30^{\circ} \mathrm{C}, 35^{\circ} \mathrm{C}$ and $40^{\circ} \mathrm{C}$, we observed values for moisture in the monolayer $\left(X_{m}\right)$ ranging from $14.87 \%$ to $15.67 \%$, according to GAB's model. It shows the moisture content values for safe storage and material stability, because, according to Ferreira and Pena [13], this parameter is extremely important, since it is related to a series of chemical reactions of deterioration. Thus, mango pulp powder requires more care when stored in places with relative humidity higher than $16 \%$ and, due to that, it is recommended the use of packages that offer resistance against moisture.

It is important to highlight that, the higher the temperature analyzed, the higher the moisture content in the monolayer, according to GAB's model. This behavior was also observed by Fiorentin et al. [14], while studying kinetics determination and drying isotherms of orange bagasse. According to Saltmarch and Labuzza [15], for foods that are rich in sugar, high water activity dissolves the sugar and crystalline sugar is converted in amorphous sugar. The amount of absorbed water gradually increases after this transition, due to the increase in number of adsorption sites, upon the rupture in the crystalline structure of sugar. This process is known as endothermic.

It is observed that parameter C of GAB's model, which represents the total sorption heat in the first layer and is related to the physical effect of temperature, showed a tendency to decrease, upon the increase in temperature. A similar behavior was observed by Moraga et al. [16], while studying adsorption isotherms of kiwi.

As for parameter $K$ of GAB's model, which represents the correction factor of the property of the molecules in the multilayer, in relation to the liquid volume, values lower than 1.0 (one) were observed, varying between

Table 1. Results for $a_{w}$ and $X_{\text {eq }}$ of mango pulp powder at different temperatures.

\begin{tabular}{|c|c|c|c|c|c|}
\hline \multirow{2}{*}{$a_{w}$ of the cells used } & \multirow{2}{*}{ Balance moisture $\left(X_{e q}\right)$} & \multicolumn{4}{|c|}{ Water activity $\left(a_{w}\right)$} \\
\hline & & $25^{\circ} \mathrm{C}$ & $30^{\circ} \mathrm{C}$ & $35^{\circ} \mathrm{C}$ & $40^{\circ} \mathrm{C}$ \\
\hline 0.21 & 0.04 & 0.34 & 0.32 & 0.30 & 0.29 \\
\hline 0.44 & 0.07 & 0.43 & 0.43 & 0.42 & 0.42 \\
\hline 0.58 & 0.12 & 0.54 & 0.54 & 0.55 & 0.54 \\
\hline 0.76 & 0.19 & 0.69 & 0.68 & 0.67 & 0.66 \\
\hline 0.84 & 0.31 & 0.78 & 0.77 & 0.77 & 0.75 \\
\hline 0.90 & 0.46 & 0.87 & 0.86 & 0.86 & 0.85 \\
\hline
\end{tabular}


Table 2. Parameters for the adjustments obtained from the mathematical models applied to the adsorption isotherms of mango pulp powder, at different temperatures.

\begin{tabular}{|c|c|c|c|c|c|c|}
\hline \multirow{2}{*}{ Models } & \multirow{2}{*}{$\mathbf{T}\left({ }^{\circ} \mathrm{C}\right)$} & \multicolumn{3}{|c|}{ Parameters } & \multirow[t]{2}{*}{$R^{2}$} & \multirow[t]{2}{*}{$E(\%)$} \\
\hline & & $X_{m}$ & C & K & & \\
\hline \multirow{5}{*}{ GAB } & 25 & 0.1487 & 0.7154 & 0.8842 & 0.9977 & 8.0934 \\
\hline & 30 & 0.1555 & 0.7130 & 0.8838 & 0.9981 & 7.0252 \\
\hline & 35 & 0.1562 & 0.7130 & 0.8864 & 0.9990 & 4.2648 \\
\hline & 40 & 0.1567 & 0.7007 & 0.9030 & 0.9985 & 4.9269 \\
\hline & & $X_{m}$ & C & $n$ & & \\
\hline \multirow{4}{*}{ BET } & 25 & 0.1105 & 1.4063 & 1.5210 & 0.9905 & 15.8010 \\
\hline & 30 & 0.1909 & 0.6714 & 1.6214 & 0.9931 & 13.4125 \\
\hline & 35 & 0.1107 & 1.4069 & 1.4680 & 0.9933 & 12.5920 \\
\hline & 40 & 0.1077 & 1.3422 & 1.3559 & 0.9942 & 10.6932 \\
\hline \multirow{6}{*}{ Henderson } & & $a$ & $b$ & & & \\
\hline & 25 & 0.6939 & 3.5302 & & 0.9979 & 6.8271 \\
\hline & 30 & 0.6927 & 3.4251 & & 0.9983 & 4.4969 \\
\hline & 35 & 0.6892 & 3.3743 & & 0.9992 & 2.3070 \\
\hline & 40 & 0.6648 & 3.1388 & & 0.9988 & 2.9387 \\
\hline & & $a$ & $b$ & & & \\
\hline \multirow{4}{*}{ Oswin } & 25 & 0.1035 & 0.7859 & & 0.9932 & 15.0748 \\
\hline & 30 & 0.1066 & 0.7984 & & 0.9939 & 13.8530 \\
\hline & 35 & 0.1079 & 0.8041 & & 0.9953 & 12.1891 \\
\hline & 40 & 0.1090 & 0.8549 & & 0.9955 & 11.0036 \\
\hline
\end{tabular}

Where: $X_{m}=$ moisture content in the molecular monolayer ( $\mathrm{g} \cdot \mathrm{g}^{-1}$ in a dry basis); $n=$ number of molecular layers; $C=\mathrm{BET}$ 's constant, related to the sorption heat in the molecular layer; $K=$ sorption constant; $a$ and $b=$ adjustment parameters.

0.8838 and 0.9030 . We also verified an increase in this parameter, as the temperature increased $\left(25^{\circ} \mathrm{C}-40^{\circ} \mathrm{C}\right) . \mathrm{A}$ similar behavior was observed by Orrego-Alzate et al. [17], while studying adsorption isotherms of tomato juice lyophilized at $20^{\circ} \mathrm{C}, 25^{\circ} \mathrm{C}, 30^{\circ} \mathrm{C}$ and $35^{\circ} \mathrm{C}$.

The parameters found for Henderson's and Oswin models are in accordance with Blahovec's [18], who affirms that Henderson's model should present $a>0$ and $b>1$, and Oswin's model should present $a>0$ and $0<b$ $<1$. These values indicate that there is no inflexion point in the curve and, therefore, there are no changes in the functions concavity. Thus, these parameters are physically and mathematically consistent.

The adsorption isotherms of mango pulp powder were obtained by tracing the balance contents of water in the powder as a function of water activity. This construction finished within 5 days, i.e., the mango pulp powder reached its hygroscopic balance within 5 days, which is a period of time much lower than the one observed by Bezerra [19], who studied the hygroscopic behavior of different types of mango powder and found out that it needed 20 days to reach this balance. The experimental values obtained showed that the behavior of the isotherms was exponential, with a type III format ( $\mathrm{J}$ format), according to Figures 1 and 2, which is characteristic of foods with high sugar content in IUPAC classification, according to Hérbrard et al. [20]. This type of curve was also observed by Gabas et al. [21], while studying pineapple pulp added with maltodextrin or gum Arabic and dried at vacuum, and by Wang, Zhang and Chen [22], while studying lyophilized gooseberry.

Another parameter that characterizes curves with $\mathrm{J}$ format, i.e., isotherms type III is constant C, because, according to Gogus, Maskan and Kaya [23], constant $C<10$ indicates isotherms with this format. It was observed that all models showed $C<10$, therefore, all isotherms are type III.

Observing Figures 1 and 2, it can be concluded that, upon low $a_{w}$, atomized mango pulp powder adsorbs small quantities of water and, upon high $a_{w}$, the powder adsorbs high quantities of water. This type of behavior was pointed out by Telis and Sobral [24] as typical of foods that are rich in sugar. The curves obtained by GAB's and Henderson's models, at all temperatures, showed that the differences among the models are well described in the interval from 0.8 to 1.0 (water activity), as it can be seen in Figures 1 and 2. 


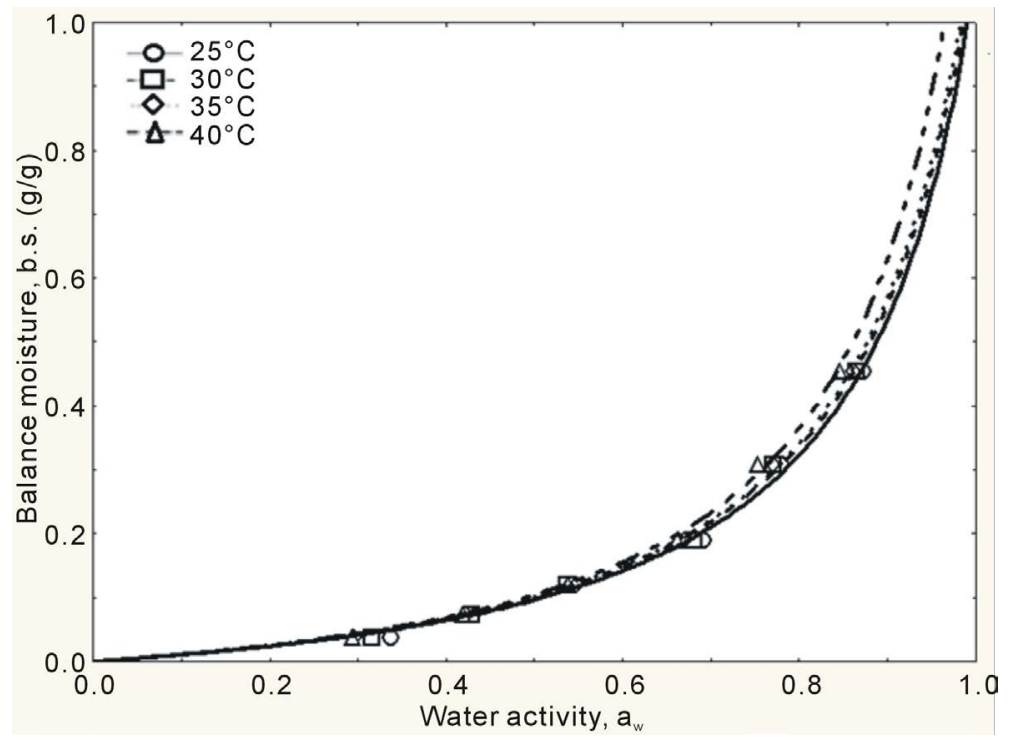

Figure 1. Adsorption isotherms of mango pulp powder, according to GAB's model, at different temperatures $\left(25^{\circ} \mathrm{C}, 30^{\circ} \mathrm{C}, 35^{\circ} \mathrm{C}\right.$ and $\left.40^{\circ} \mathrm{C}\right)$.

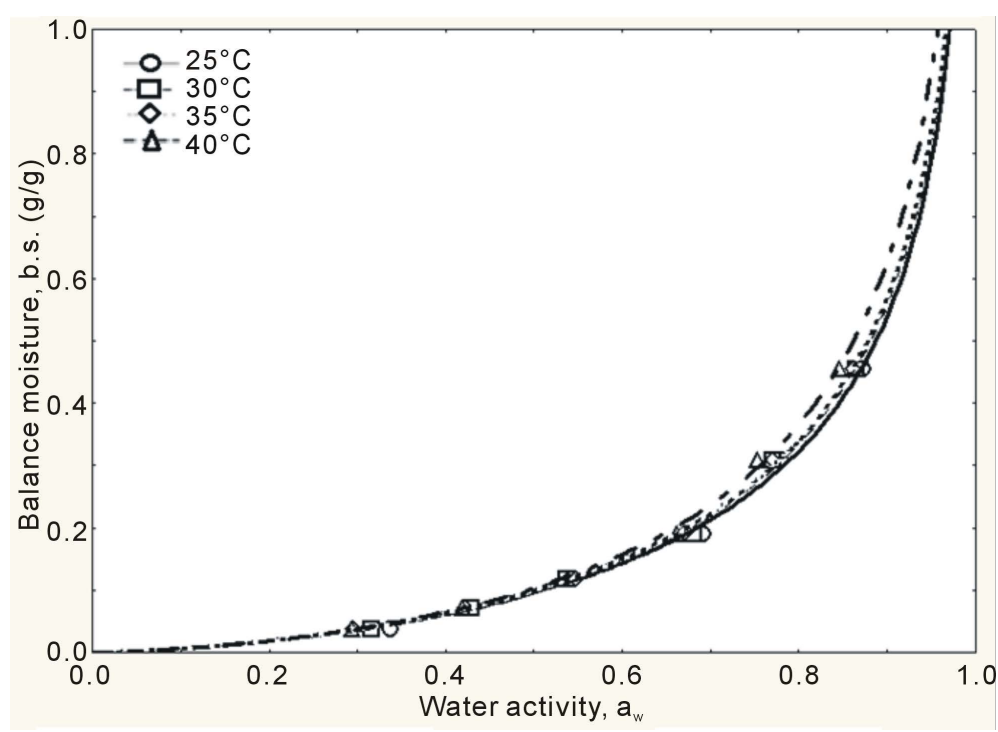

Figure 2. Adsorption isotherms of mango pulp powder, according to Henderson's model, at different temperatures $\left(25^{\circ} \mathrm{C}, 30^{\circ} \mathrm{C}, 35^{\circ} \mathrm{C}\right.$ and $\left.40^{\circ} \mathrm{C}\right)$.

\section{Conclusions}

Henderson's model, at all temperatures, was the one that adjusted the best, with average error ranging from 2.31\% to $6.683 \%$ and determination coefficient ranging from 0.9979 to 0.9992 , followed by GAB's model. Both of them are able to represent the adsorption isotherms of mango pulp powder.

Water content in the mango pulp powder showed a tendency to grow as the water activity increased and the moisture values in the monolayer indicate that mango pulp powder is stable to a level of moisture of $16 \%$ in storage. Upon higher moisture percentages, the stability of mango pulp powder will be lower; therefore, it is recommended the use of packages that offer resistance against moisture.

\section{Acknowledgements}

The authors thank CNPq, through INCT, for the support to this project, and Federal University of Ceará, for 
ceding its infrastructure.

\section{References}

[1] Silva, C.R.R., Fonseca, E.B.A. and Moreira, M.A. (2010) A Cultura da Mangueira. In: Boletins Técnicos e de Extensão. Editora UFLA, 5-120.

[2] IBGE-Instituto Brasileiro de Geografia e Estatística (2011) Produção Agrícola Municipal. http://www.sidra.ibge.gov.br/bda/tabela/listabl.asp?z=t\&o=11\&i=P\&c=1613

[3] Alexandre, H.V., Figueiredo, R.M.F. and Queiroz, A.J. de M. (2007) Isotermas de Adsorção de Umidade da Pitanga em pó. Revista de Biologia e Ciências da Terra, 7.

[4] Anselmo, G.C.S., Mata, M.E.R.M.C., Arruda, P.C. and Sousa, M.C. (2006) Determinação da Higroscopicidade do Cajá em pó por meio da Secagem por Atomização. Revista de Biologia e Ciências da Terra. Campina Grande, 6, 58-65.

[5] Vieira, A.H., Figueirêdo, R.M.F. and Queiroz, A.J.M. (2007) Isotermas de Adsorção de Umidade da Pitanga em pó. Revista de Biologia e Ciências da Terra, 7, 11-20.

[6] Berteli, M.N. (2005) Estudo Comparativo de Processos de Secagem de Sólidos Granulados com e Sem Assistência de Microondas. 134f. Tese (Doutorado)—Engenharia de Alimentos—Faculdade de Engenharia de Alimentos da Universidade Estadual de Campinas. Campinas, São Paulo.

[7] AQUALAB (1997) Analisador de Atividade de Água Decagon. ABRASEQ, Brasil.

[8] Spiess, W.E.L. and Wolf, W.R. (1983) Cost 90 European Cooperation in Scientific and Technical. Research. In: Jowitt, R., Ed., Physical Properties of Foods. Applied Science Publication, London, 65-87.

[9] Greenspan, L. (1977) Humidity Fixed Poins of Binary Saturated Agneoussotutions. Journal Research Nature Physics Chemistry, 81A.

[10] Toloba, M.P., Peltzer, M., Enriquez, N. and Pollio, M.L. (2004) Grainsorptionequilibriaofquinoagrains. Journal of Food Engineering, 61, 365-371.

[11] Park, K.J., Bin, A. and Brod, F.P.R. (2001) Obtenção das Isotermas de Sorção e Modelagem Matemática para a Pêrabartlett (Pyrussp.) com e sem Desidratação Osmótica. Ciência e Tecnologia de Alimentos, Campinas, 21, 73-77. http://dx.doi.org/10.1590/S0101-20612001000100016

[12] Labuza, T. P., Kaanane, A. and Chen, J.Y. (1985) Effects of Temperature on the Moisture Sorption Isotherms and Water Activity Shift of Two Dehydrated Foods. Journal of Food Science, 50, 385-392. http://dx.doi.org/10.1111/j.1365-2621.1985.tb13409.x

[13] Ferreira, C.D. and Pena, R.S. (2003) Comportamento Higroscópico da Farinha de Pupunha (Bactrisgasipaes). Ciência e Tecnologia de Alimentos, Campinas, 23, 251-255. http://dx.doi.org/10.1590/S0101-20612003000200025

[14] Fiorentin, L.D., Menon, B.T., Alves, J.A., Barros, S.T.D., Pereira, N.C. and Módenes, A.N. (2010) Determinação da Cinética e das Isotermas de Secagem do Bagaço de Laranja. ActaScientiarum, Technology, 32, 147-152.

[15] Saltmarch, M. and Labuzza, T.P. (1980) Influence of Relative Humidity on the Physiochemical State of Lactose in Spray-Dried Sweet Whey Powders. Journal of Food Science, 45, 1231-1236. http://dx.doi.org/10.1111/j.1365-2621.1980.tb06528.x

[16] Moraga, G., Martínez-Navarrete, A. and Chiralt, A. (2006) Water Sorption Isotherms and Phase Transitions in Kiwifruit. Journal of Food Engineering, 72, 147-156. http://dx.doi.org/10.1016/j.jfoodeng.2004.11.031

[17] Orrego-Alzate, C.E., Giraldo-Gómez, G.I. and González-Jiménez, M.E. (2005) Calorimetric Study and Adsorption Isotherms of Freeze-Dried Tomato Tree (Cyphomandrabetacea(Cav) Send) Juice. In: Mercosur Congress on Chemical Engineering, 2, Mercosur Congress on Process Systems Engineering, 4, Rio de Janeiro.

[18] Blahovec, J. (2004) Sorption Isotherms in Materials of Biological Origin Mathematical and Physical Approach. Journal of Food Engineering, 65, 489-495. http://dx.doi.org/10.1016/j.jfoodeng.2004.02.012

[19] Bezerra, S.T. (2009) Comportamento Higroscópico de pós de Diferentes Variedades de Manga (Mangifeta indica L.). 100f. Dissertação (Mestrado em Tecnologia de Alimentos), Universidade Federal do Ceará, Fortaleza.

[20] Hérbrard, A., Oulahna, D., Galet, L., Cuq, B., Abecassis, J. and Fages, J. (2003) Hydration Properties of Durum Wheat Semolina: Influence of Particle Size. Powder Technology, 130, 211-218. http://dx.doi.org/10.1016/S0032-5910(02)00268-1

[21] Gabas, A.L., Telis, V.R.N., Sobral, P.J.A. and Telis-Romero, J. (2007) Effect of Maltodextrin and Arabic Gum in Water Vapor Sorption Thermodynamic Properties of Vacuum Dried Pineapple Pulp Powder. Journal of Food Engineering, 82, 246-252. http://dx.doi.org/10.1016/j.jfoodeng.2007.02.029

[22] Wang, H., Zhang, S. and Chen, G. (2008) Glass Transition and State Diagram for Fresh and Freeze-Dried Chinese Gooseberry. Journal of Food Engineering, 84, 307-312. http://dx.doi.org/10.1016/j.jfoodeng.2007.05.024 
[23] Gogus, F., Maskan, M. and Kaya, A. (1998) Sorption Isotherms of Turkish Delight. Journal of Food Protection, 22, 345-357.

[24] Telis, V.R.N. and Sobral, P.J.A. (2001) Glass Transitions and State Diagram for Freeze-Dried Pineapple. Lebensmittel Wissenchaft \& Technology, 34, 199-205. 